\title{
On the Hydrolysis Step in Osmium Catalyzed Asymmetric
}

\section{Dihydroxylations}

\author{
Mikko H. Junttila and Osmo E. O. Hormi*
}

Department of Chemistry, University of Oulu, P.O. Box 3000, FIN-90014 University of Oulu, Finland,

Fax: (+356) 8553 1593, E-mail: osmo.hormi@ oulu.fi

\section{Supporting Information}

\section{Table of Contents:}

The rate expressions $\quad$ S2

General procedure and kinetic data of the $\mathrm{NaClO}_{2}$-dihydroxylations of $8.5 \mathrm{mM}$ solutions of olefin $\mathbf{S 3}$

Pseudo-first-order fittings and pseudo-first-order reaction constants of catalytic asymmetric

$\mathrm{NaClO}_{2}$-dihydroxylations of $8.5 \mathrm{mM}$ solutions of substituted styrenes $\mathbf{S 3}$

General procedure and kinetic data of the $\mathrm{K}_{3}\left[\mathrm{Fe}(\mathrm{CN})_{6}\right]$-dihydroxylations of $8.5 \mathrm{mM}$ solutions of olefin $\quad \mathbf{S 3}$

The pseudo-first-order fittings and pseudo-first-order reaction constants of catalytic asymmetric

$\mathrm{K}_{3}\left[\mathrm{Fe}(\mathrm{CN})_{6}\right]$-dihydroxylations of $8.5 \mathrm{mM}$ solutions of substituted styrenes.

S4

General procedure for the solvent kinetic isotope effect studies of $\mathrm{NaClO}_{2}$ - and $\mathrm{K}_{3}\left[\mathrm{Fe}(\mathrm{CN})_{6}\right]$-dihydroxylations $\mathbf{S 4}$

The pseudo-first-order fittings and pseudo-first-order reaction constants of catalytic asymmetric $\mathrm{NaClO}_{2}$ -

and $\mathrm{K}_{3}\left[\mathrm{Fe}(\mathrm{CN})_{6}\right]$-dihydroxylations of $8.5 \mathrm{mM}$ solutions of $p$-methoxystyrene and $p$-cyanostyrene in

${ }^{\mathrm{t}} \mathrm{BuOH} / \mathrm{D}_{2} \mathrm{O}(1: 1)$-mixture

Table of Pseudo-First-Order Rate Constants of Dihydroxylation of $8.5 \mathrm{mM}$ Solutions of Substituted Styrenes in ${ }^{t} \mathrm{BuOH} / \mathrm{H}_{2} \mathrm{O}(1: 1)$ - and ${ }^{\mathrm{t}} \mathrm{BuOH} / \mathrm{D}_{2} \mathrm{O}(1: 1)$-mixtures.

${ }^{1} \mathrm{H}$ NMR spectra of the product and ${ }^{1} \mathrm{H}$ NMR spectra of the bis(Mosher's)ester of the product from $\mathrm{K}_{3}\left[\mathrm{Fe}(\mathrm{CN})_{6}\right]$-dihydroxylation of styrene

${ }^{1} \mathrm{H}$ NMR spectra of the product and ${ }^{1} \mathrm{H}$ NMR spectra of the bis(Mosher's)ester of the product from $\mathrm{NaClO}_{2}$-dihydroxylation of styrene

${ }^{1} \mathrm{H}$ NMR spectra of the product and ${ }^{1} \mathrm{H}$ NMR spectra of the bis(Mosher's)ester of the product from $\mathrm{NaClO}_{2}$-dihydroxylation of $p$-methoxystyrene

${ }^{1} \mathrm{H}$ NMR spectra of the product and ${ }^{1} \mathrm{H}$ NMR spectra of the bis(Mosher's)ester of the product from $\mathrm{K}_{3}\left[\mathrm{Fe}(\mathrm{CN})_{6}\right]$-dihydroxylation of $p$-methoxystyrene

${ }^{1} \mathrm{H}$ NMR spectra of the product and ${ }^{1} \mathrm{H}$ NMR spectra of the bis(Mosher's)ester of the product from $\mathrm{K}_{3}\left[\mathrm{Fe}(\mathrm{CN})_{6}\right]$-dihydroxylation of $p$-cyanostyrene

${ }^{1} \mathrm{H}$ NMR spectra of the product and ${ }^{1} \mathrm{H}$ NMR spectra of the bis(Mosher's)ester of the product from $\mathrm{NaClO}_{2}$-dihydroxylation of $p$-cyanostyrene 
The rate expressions:

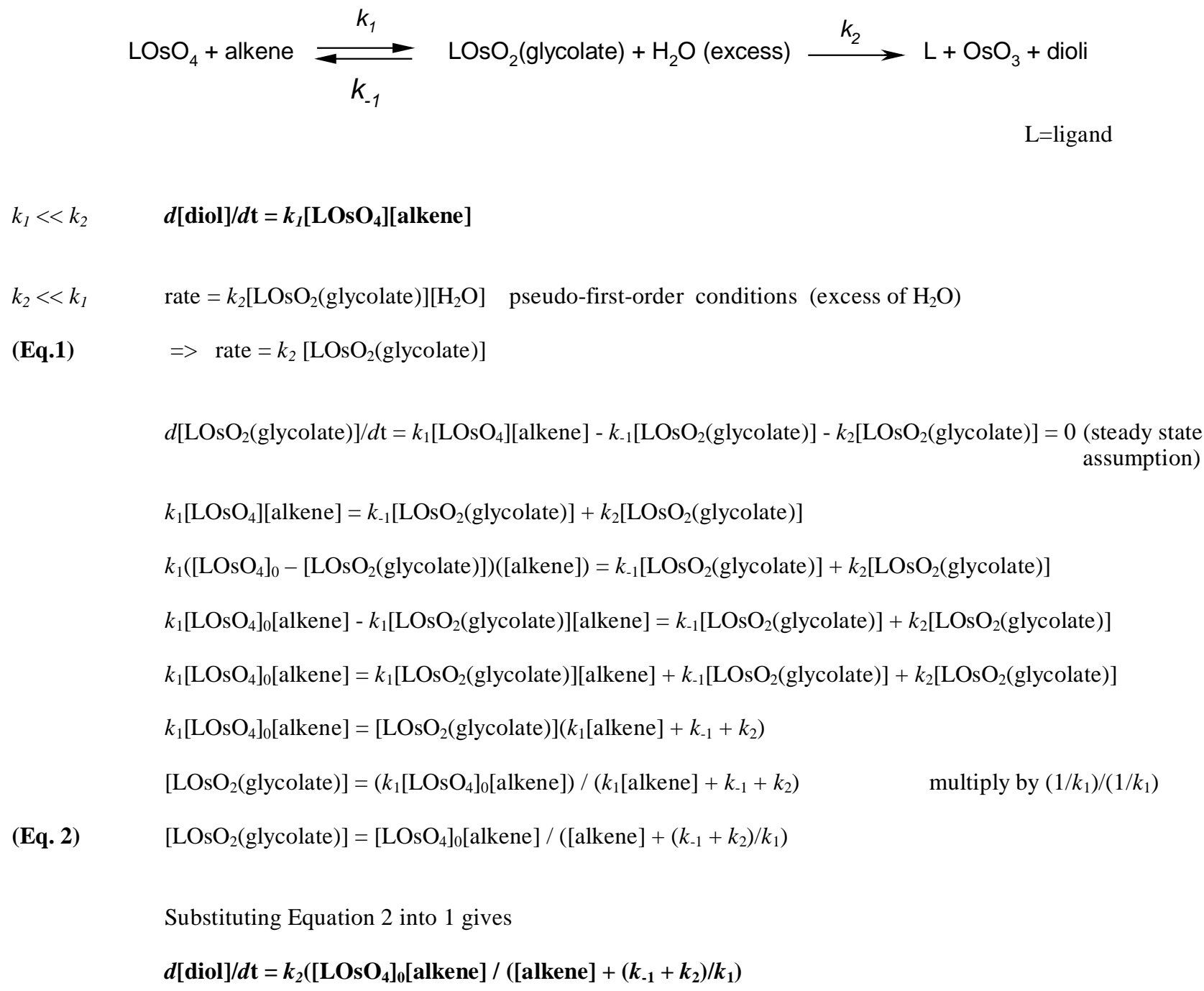


General procedure for the $\mathrm{NaClO}_{2}$-dihydroxylations of $8.5 \mathrm{mM}$ solutions of olefin: A $50 \mathrm{~mL}$ three-necked flask equipped with a magnetic stirring bar, $\mathrm{pH}$ electrode and thermometer was charged with $0.085 \mathrm{mmols}$ of olefin, $7.3 \mathrm{mg}$ (1.5 equiv, $0.065 \mathrm{mmol})$ of $\mathrm{NaClO}_{2}(80 \%), 1.5 \mathrm{mg}(1.9 \mu \mathrm{mol}, 2.2 \mathrm{~mol} \%)$ of ligand ((DHQD) $\left.{ }_{2} \mathrm{PHAL}\right), 0,83 \mathrm{~g}(6.0 \mathrm{mmol})$ of $\mathrm{K}_{2} \mathrm{CO}_{3}$ and $10 \mathrm{~mL}$ of ${ }^{\mathrm{t}} \mathrm{BuOH} / \mathrm{H}_{2} \mathrm{O}$ (1:1)-mixture. $\mathrm{pH}$ was adjusted to 11.5 with $\mathrm{NaHCO}_{3}$. Reaction was initiated by adding $76 \mu \mathrm{l}(0.90$ $\mathrm{mol} \%$ ) of $10 \mathrm{mM} \mathrm{K}_{2} \mathrm{OsO}_{4} 2 \mathrm{H}_{2} \mathrm{O}$-solution to a cooled $\left(0.5{ }^{\circ} \mathrm{C}\right)$ reaction mixture. The reactions were followed by monitoring the consumption of olefin. $20 \mu \mathrm{L}$ aliquots were withdrawn from the reaction mixture after a period of time. Reaction was quenched by diluting the sample with mixture containing $20 \mu \mathrm{L}$ of $60 \mathrm{mM}$ solution of $\mathrm{Na}_{2} \mathrm{SO}_{3}$ and $20 \mu \mathrm{L}$ of $0.017 \mathrm{mM}$ of acetophenon (standard) in EtOAc. Sample was dried with $\mathrm{Na}_{2} \mathrm{SO}_{4}$ prior analysis with GC. Products were isolated from the reactions were $p$-methoxystyrene, styrene or $p$-cyanostyrene was the substrate. $80 \mathrm{mg}$ of $\mathrm{Na}_{2} \mathrm{SO}_{3}$ was added and the reaction mixture was warmed to room temperature and stirred for $30 \mathrm{~min}$. Reaction mixture was transferred to $50 \mathrm{~mL}$ separating funnel with $10 \mathrm{~mL}$ of EtOAc. Phases were separated and the organic layer was washed with $5 \mathrm{~mL}$ of $1.2 \mathrm{M} \mathrm{HCl,} 5 \mathrm{~mL}$ of saturated $\mathrm{Na}_{2} \mathrm{CO}_{3}$ and $5 \mathrm{~mL}$ of brine. Organic layer was dried with $\mathrm{Na}_{2} \mathrm{SO}_{4}$, filtrated and the solvent was removed on a rotary evaporator.

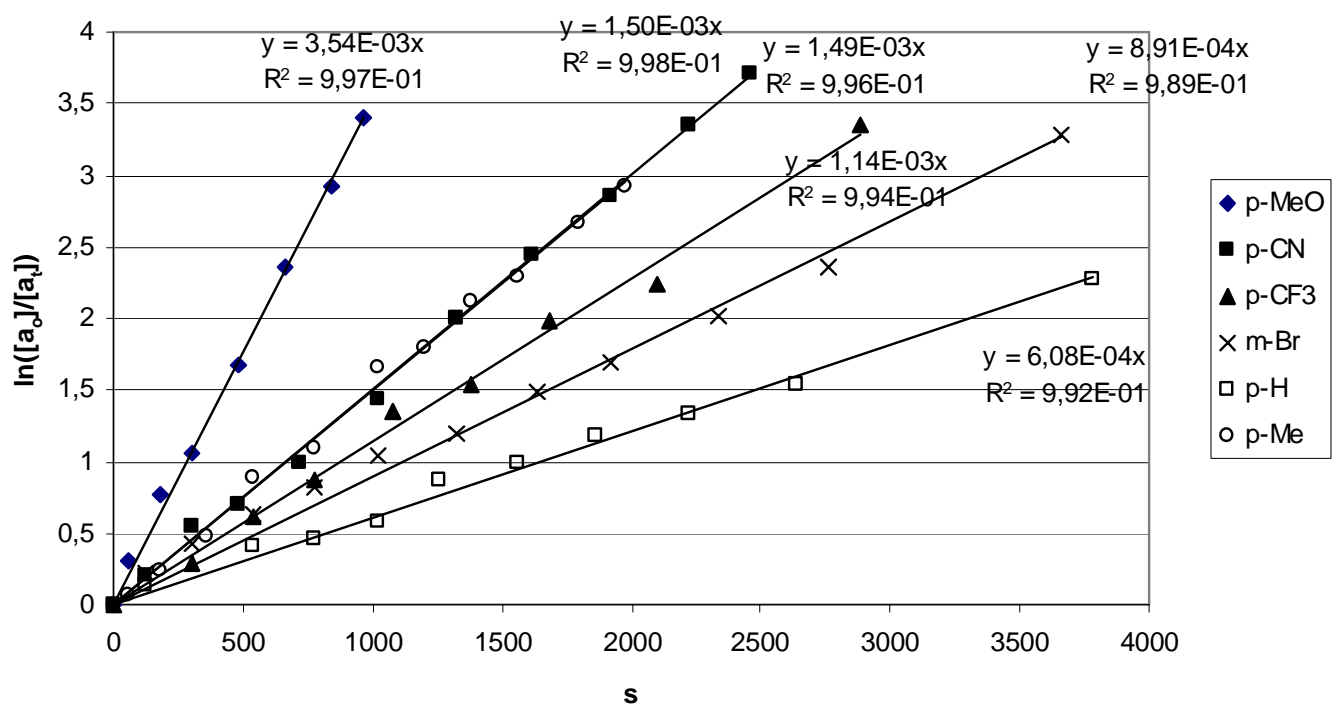

Figure 1. Pseudo-first-order fittings and pseudo-first-order reaction constants of catalytic asymmetric $\mathrm{NaClO}_{2}$ dihydroxylations of $8.5 \mathrm{mM}$ solutions of substituted styrenes.

General procedure for the $\mathrm{K}_{3}\left[\mathrm{Fe}(\mathrm{CN})_{6}\right]$-dihydroxylations of $0.085 \mathrm{mM}$ solutions of olefin: A $50 \mathrm{~mL}$ three-necked flask equipped with a magnetic stirring bar, $\mathrm{pH}$ electrode and thermometer was charged with $0.085 \mathrm{mmols}$ of olefin, $0.085 \mathrm{~g}(3$ equiv, $0.26 \mathrm{mmol})$ of $\mathrm{K}_{3}\left[\mathrm{Fe}(\mathrm{CN})_{6}\right], 1.5 \mathrm{mg}(1.9 \mu \mathrm{mol}, 2.2 \mathrm{~mol} \%)$ of ligand ((DHQD) $\left.{ }_{2} \mathrm{PHAL}\right), 0.83 \mathrm{~g}(6 \mathrm{mmol})$ of $\mathrm{K}_{2} \mathrm{CO}_{3}$ and $10 \mathrm{~mL}$ of ${ }^{\mathrm{t}} \mathrm{BuOH} / \mathrm{H}_{2} \mathrm{O}(1: 1)$-mixture. $\mathrm{pH}$ was adjusted to 11.5 with $\mathrm{NaHCO}_{3}$. Reaction was initiated by adding $76 \mu \mathrm{l}(0.9$ $\mathrm{mol} \%)$ of $10 \mathrm{mM} \mathrm{K}_{2} \mathrm{OsO}_{4} 2 \mathrm{H}_{2} \mathrm{O}$-solution to a cooled $\left(0.5^{\circ} \mathrm{C}\right)$ reaction mixture. The reactions were followed by monitoring the consumption of olefin. $20 \mu \mathrm{L}$ aliquots were withdrawn from the reaction mixture after a period of time. Reaction was quenched by diluting the sample with mixture containing $20 \mu \mathrm{L}$ of $60 \mathrm{mM}$ solution of $\mathrm{Na}_{2} \mathrm{SO}_{3}$ and $20 \mu \mathrm{L}$ of $0.017 \mathrm{mM}$ of acetophenon (standard) in EtOAc. Sample was dried with $\mathrm{Na}_{2} \mathrm{SO}_{4}$ prior analysis with GC. Products were isolated from the reactions were $p$-methoxystyrene, styrene or $p$-cyanostyrene was the substrates. $80 \mathrm{mg}$ of $\mathrm{Na}_{2} \mathrm{SO}_{3}$ was added and the reaction mixture was warmed to room temperature and stirred for $30 \mathrm{~min}$. Reaction mixture was transferred to $50 \mathrm{~mL}$ separating funnel with $10 \mathrm{~mL}$ of EtOAc. Phases were separated and the organic layer was washed with $5 \mathrm{~mL}$ of $1.2 \mathrm{M} \mathrm{HCl,} 5 \mathrm{~mL}$ of saturated $\mathrm{Na}_{2} \mathrm{CO}_{3}$ and $5 \mathrm{~mL}$ of brine. Organic layer was dried with $\mathrm{Na}_{2} \mathrm{SO}_{4}$, filtrated and the solvent was removed on a rotary evaporator. 


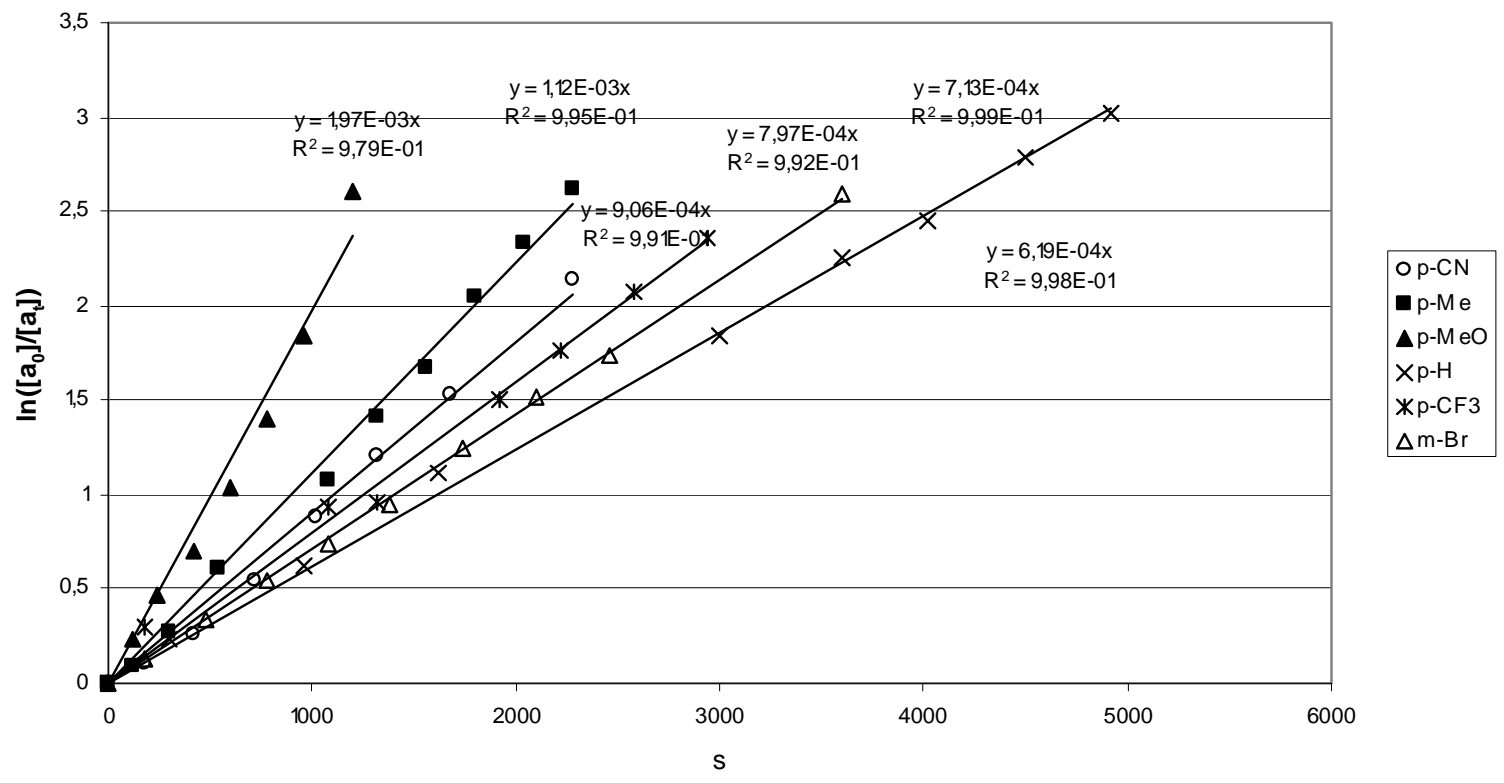

Figure 2. The pseudo-first-order fittings and pseudo-first-order reaction constants of catalytic asymmetric $\mathrm{K}_{3}\left[\mathrm{Fe}(\mathrm{CN})_{6}\right]-$ dihydroxylations of $8.5 \mathrm{mM}$ solutions of substituted styrenes.

General procedure for the solvent kinetic isotope effect studies of $\mathrm{NaClO}_{2}$-dihydroxylations: A $50 \mathrm{~mL}$ three-necked flask equipped with a magnetic stirring bar, $\mathrm{pH}$ electrode and thermometer was charged with 0.085 mmols of $p$ methoxystyrene or $p$-cyanostyrene, $7.3 \mathrm{mg}$ (1.5 equiv, $0.065 \mathrm{mmol})$ of $\mathrm{NaClO}_{2}(80 \%), 1.5 \mathrm{mg}(1.9 \mu \mathrm{mol}, 2.2 \mathrm{~mol} \%)$ of ligand ((DHQD) $\left.)_{2} \mathrm{PHAL}\right), 0,83 \mathrm{~g}(6.0 \mathrm{mmol})$ of $\mathrm{K}_{2} \mathrm{CO}_{3}$ and $10 \mathrm{~mL}$ of ${ }^{\mathrm{t}} \mathrm{BuOH} / \mathrm{D}_{2} \mathrm{O}(1: 1)$-mixture. $\mathrm{pH}$ was adjusted to $11.5 \mathrm{with}$ $\mathrm{NaHCO}_{3}$. Reaction was initiated by adding $76 \mu \mathrm{l}(0.90 \mathrm{~mol} \%)$ of $10 \mathrm{mM} \mathrm{K} \mathrm{OsO}_{4} 2 \mathrm{H}_{2} \mathrm{O}$-solution to a cooled $\left(0.5^{\circ} \mathrm{C}\right)$ reaction mixture. The reactions were followed by monitoring the consumption of olefin. $20 \mu \mathrm{L}$ aliquots were withdrawn from the reaction mixture after a period of time. Reaction was quenched by diluting the sample with mixture containing $20 \mu \mathrm{L}$ of 60 $\mathrm{mM}$ solution of $\mathrm{Na}_{2} \mathrm{SO}_{3}$ and $20 \mu \mathrm{L}$ of $0.017 \mathrm{mM}$ of acetophenon (standard) in EtOAc. Sample was dried with $\mathrm{Na}_{2} \mathrm{SO}_{4}$ prior analysis with GC.

General procedure for the solvent kinetic isotope effect studies of $\mathrm{K}_{3}\left[\mathrm{Fe}(\mathrm{CN})_{6}\right]$-dihydroxylations: A $50 \mathrm{~mL}$ threenecked flask equipped with a magnetic stirring bar, $\mathrm{pH}$ electrode and thermometer was charged with 0.085 mmols of $p$ methoxystyrene or $p$-cyanostyrene, $0.085 \mathrm{~g}$ (3 equiv, $0.26 \mathrm{mmol})$ of $\mathrm{K}_{3}\left[\mathrm{Fe}(\mathrm{CN})_{6}\right], 1.5 \mathrm{mg}(1.9 \mu \mathrm{mol}, 2.2 \mathrm{~mol} \%)$ of ligand ((DHQD) $\left.{ }_{2} \mathrm{PHAL}\right), 0.83 \mathrm{~g}(6 \mathrm{mmol})$ of $\mathrm{K}_{2} \mathrm{CO}_{3}$ and $10 \mathrm{~mL}$ of ${ }^{\mathrm{t}} \mathrm{BuOH} / \mathrm{D}_{2} \mathrm{O}(1: 1)$-mixture. $\mathrm{pH}$ was adjusted to 11.5 with $\mathrm{NaHCO}_{3}$. Reaction was initiated by adding $76 \mu \mathrm{l}(0.9 \mathrm{~mol} \%)$ of $10 \mathrm{mM} \mathrm{K}_{2} \mathrm{OsO}_{4} \cdot 2 \mathrm{H}_{2} \mathrm{O}$-solution to a cooled $\left(0.5^{\circ} \mathrm{C}\right)$ reaction mixture. The reactions were followed by monitoring the consumption of olefin. $20 \mu \mathrm{L}$ aliquots were withdrawn from the reaction mixture after a period of time. Reaction was quenched by diluting the sample with mixture containing $20 \mu \mathrm{L}$ of $60 \mathrm{mM}$ solution of $\mathrm{Na}_{2} \mathrm{SO}_{3}$ and $20 \mu \mathrm{L}$ of $0.017 \mathrm{mM}$ of acetophenon (standard) in EtOAc. Sample was dried with $\mathrm{Na}_{2} \mathrm{SO}_{4}$ prior analysis with GC. 


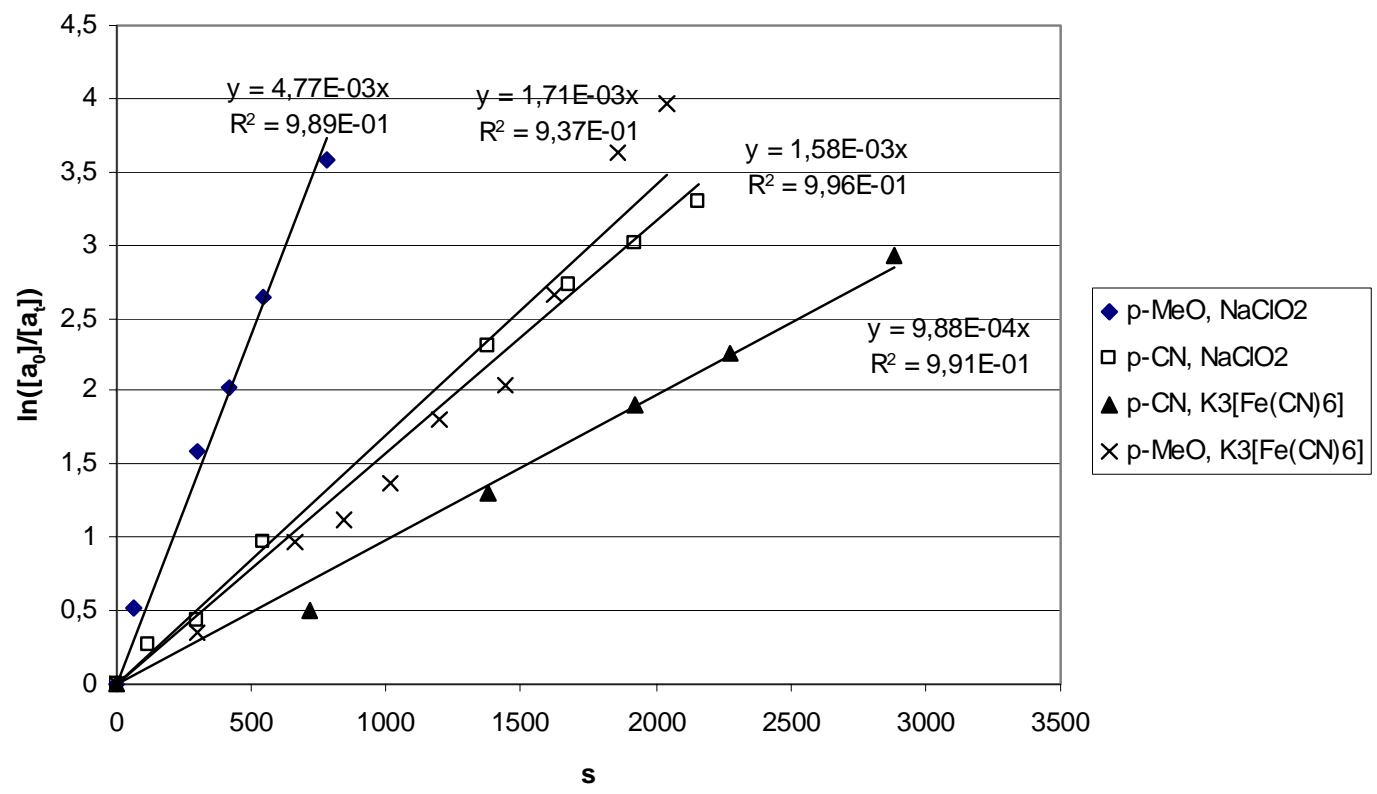

Figure 3. The pseudo-first-order fittings and pseudo-first-order reaction constants of catalytic asymmetric $\mathrm{NaClO}_{2}-$ and $\mathrm{K}_{3}\left[\mathrm{Fe}(\mathrm{CN})_{6}\right]$-dihydroxylations of $8.5 \mathrm{mM}$ solutions of $p$-methoxystyrene and $p$-cyanostyrene in ${ }^{\mathrm{t}} \mathrm{BuOH} / \mathrm{D}_{2} \mathrm{O}(1: 1)$-mixture.

Table 1. Pseudo-First-Order Rate Constants of $\mathrm{NaClO}_{2^{-}}$and $\mathrm{K}_{3}\left[\mathrm{Fe}(\mathrm{CN})_{6}\right]$-dihydroxylations of $8.5 \mathrm{mM}$ Solutions of Substituted Styrenes in ${ }^{\mathrm{t}} \mathrm{BuOH} / \mathrm{H}_{2} \mathrm{O}(1: 1)$ - and ${ }^{\mathrm{t}} \mathrm{BuOH} / \mathrm{D}_{2} \mathrm{O}(1: 1)$-mixtures.

\begin{tabular}{|c|c|c|c|c|c|}
\hline \multirow{2}{*}{ styrene } & \multicolumn{2}{|c|}{$\mathrm{NaClO}_{2}$} & \multicolumn{2}{c|}{$\mathrm{K}_{3}\left[\mathrm{Fe}(\mathrm{CN})_{6}\right]$} & \multirow{2}{*}{$\sigma^{\mathrm{a}}$} \\
\cline { 2 - 5 } & $10^{-4} k\left(\mathrm{~s}^{-1}\right)$ & $\log \left(k_{\mathrm{X}} / k_{\mathrm{H}}\right)$ & $10^{-4} k\left(\mathrm{~s}^{-1}\right)$ & $\log \left(k_{\mathrm{X}} / k_{\mathrm{H}}\right)$ & \\
\hline$p-\mathrm{MeO}$ & $35.4 \pm 0.6^{\mathrm{b}}$ & 0.76 & $19.7 \pm 0.7$ & 0.50 & -0.28 \\
\hline$p-\mathrm{Me}$ & $14.9 \pm 0.3$ & 0.39 & $11.2 \pm 0.3$ & 0.26 & -0.14 \\
\hline$p-\mathrm{H}$ & $6.1 \pm 0.1$ & 0.00 & $6.2 \pm 0.1$ & 0.00 & 0.00 \\
\hline$m-\mathrm{Br}$ & $8.9 \pm 0.2$ & 0.16 & $7.1 \pm 0.4$ & 0.06 & 0.37 \\
\hline$p-\mathrm{CF}_{3}$ & $11.4 \pm 0.3$ & 0.27 & $8.0 \pm 0.4$ & 0.11 & 0.53 \\
\hline$p-\mathrm{CN}^{*}$ & $15.0 \pm 0.2$ & 0.39 & $9.6 \pm 0.2$ & 0.19 & 0.70 \\
\hline$p-\mathrm{MeO}^{\mathrm{c}}$ & $47.7 \pm 1.7$ & & $\mathrm{~d}$ & & \\
\hline$p-\mathrm{CN}^{\mathrm{c}}$ & $15.6 \pm 0.4$ & & $9.9 \pm 0.4$ & & \\
\hline
\end{tabular}

${ }^{\text {a }}$ March, J. Advanced organic chemistry: reactions, mechanism, and structure $-4^{\text {th }}$ ed.: John Wiley \& Sons New York 1992 pp. $280 .{ }^{b} 95 \%$ confidence level ${ }^{c}$ in ${ }^{t} \mathrm{BuOH} / \mathrm{D}_{2} \mathrm{O}(1: 1)$-mixture, ${ }^{\mathrm{d}}$ reaction did not follow pseudo-first-order kinetics 
${ }^{1} \mathrm{H}$ NMR-spectra of the product 1 phenylethane-1,2-diol from the $\mathrm{K}_{3}\left[\mathrm{Fe}(\mathrm{CN})_{6}\right]$-dihydroxylation of styrene (200 MHz, $d$-acetone).<smiles>OCC(O)c1ccccc1</smiles>

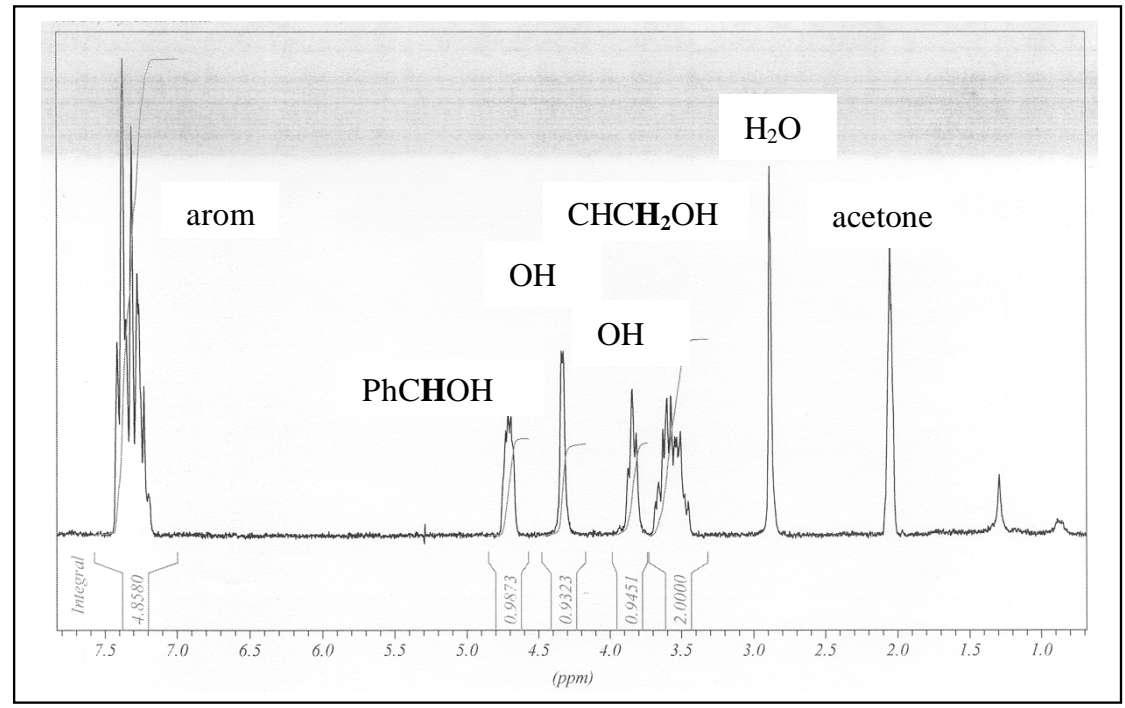

${ }^{1} \mathrm{H} \quad \mathrm{NMR}$ spectra of the bis(Mosher's)ester of the product from the $\mathrm{K}_{3}\left[\mathrm{Fe}(\mathrm{CN})_{6}\right]$ dihydroxylation of styrene (400 $\mathrm{MHz}, d$-acetone). ${ }^{1}$<smiles>COC(C(=O)OCC(OC(=O)C(F)(c1ccccc1)C(F)(F)F)c1ccccc1)(c1ccccc1)C(F)(F)F</smiles>

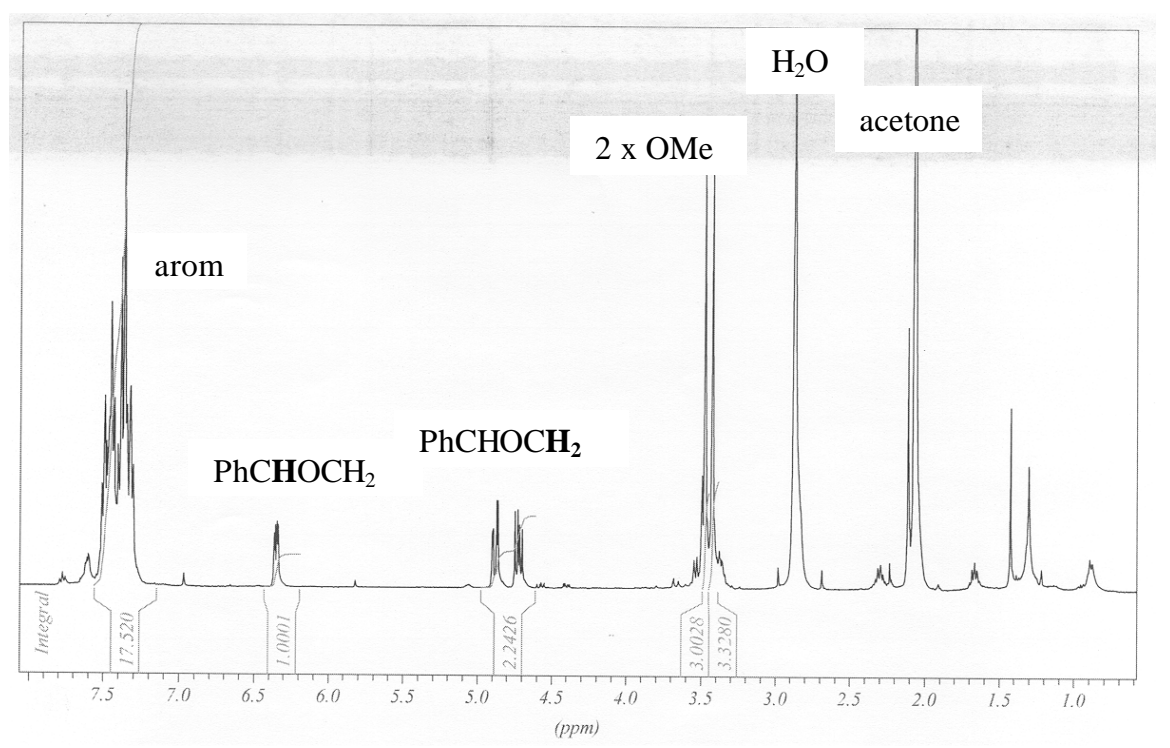

$\mathrm{PhCHOCH}_{2}$

$\mathrm{Ee} \%=98.85-1.15=97.7$

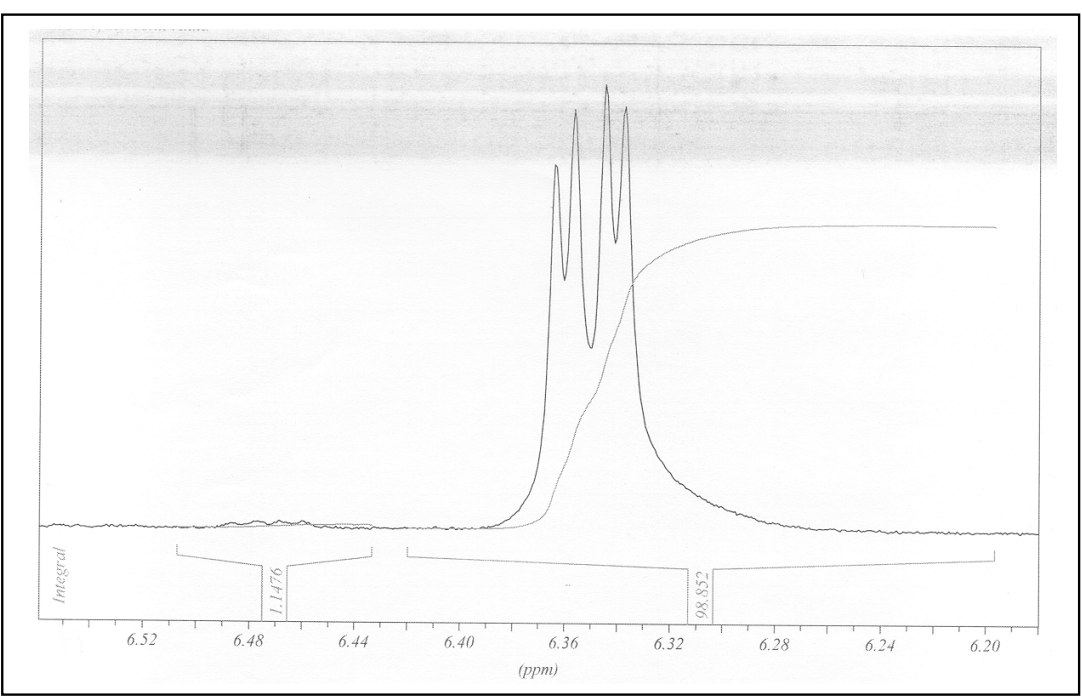



$\mathrm{NaClO}_{2}$-dihydroxylation of styrene (200 MHz, $d$-acetone).<smiles>OCC(O)c1ccccc1</smiles>

${ }^{1} \mathrm{H}$ NMR-spectra of the product 1phenylethane-1,2-diol from the

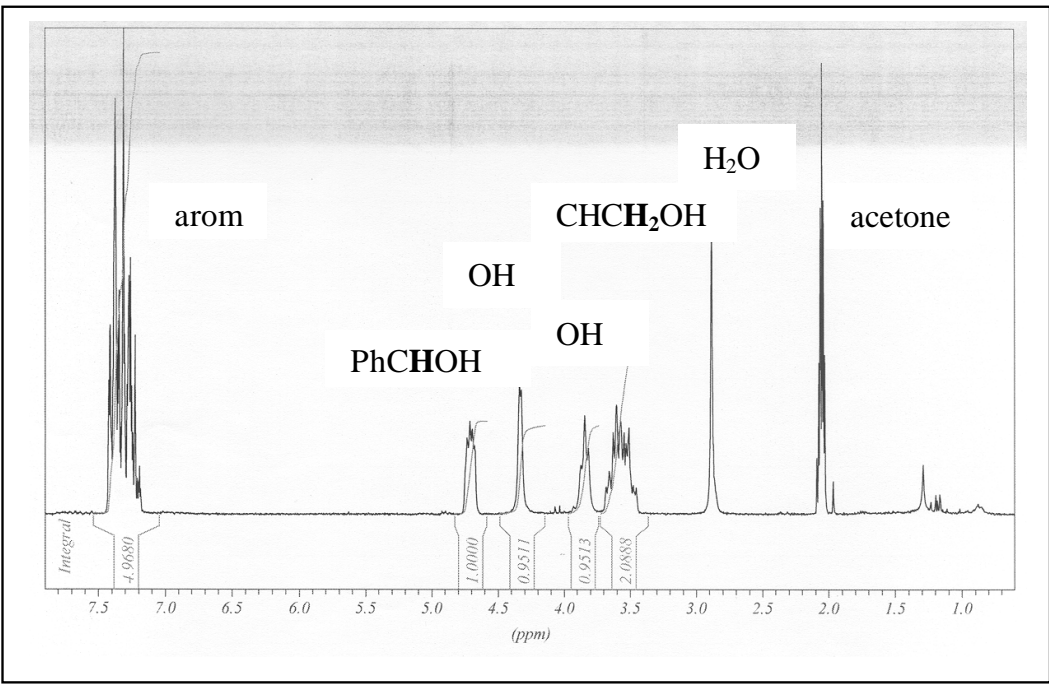

${ }^{1} \mathrm{H} \quad$ NMR spectra of the bis(Mosher's)ester of the product from the $\mathrm{NaClO}_{2}$-dihydroxylation of styrene (400 MHz, $d$-acetone). ${ }^{1}$<smiles>COC(C(=O)OCC(OC(=O)C(F)(c1ccccc1)C(F)(F)F)c1ccccc1)(c1ccccc1)C(F)(F)F</smiles>

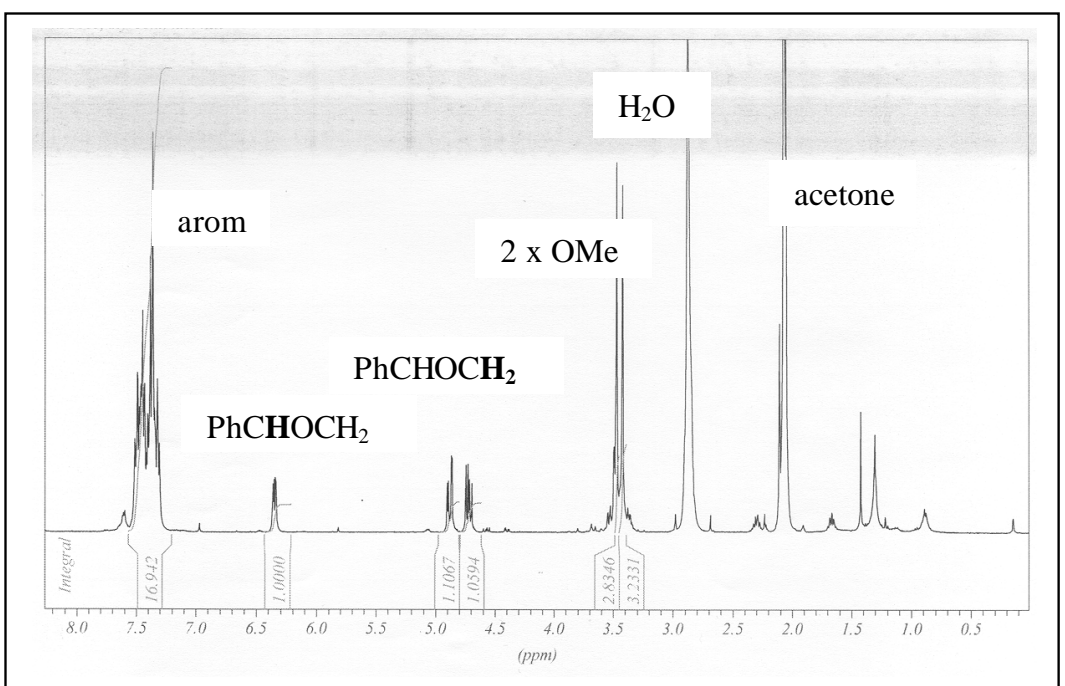

$\mathrm{PhCHOCH}_{2}$

$\mathrm{Ee} \%=97.83-2.17=95.66$

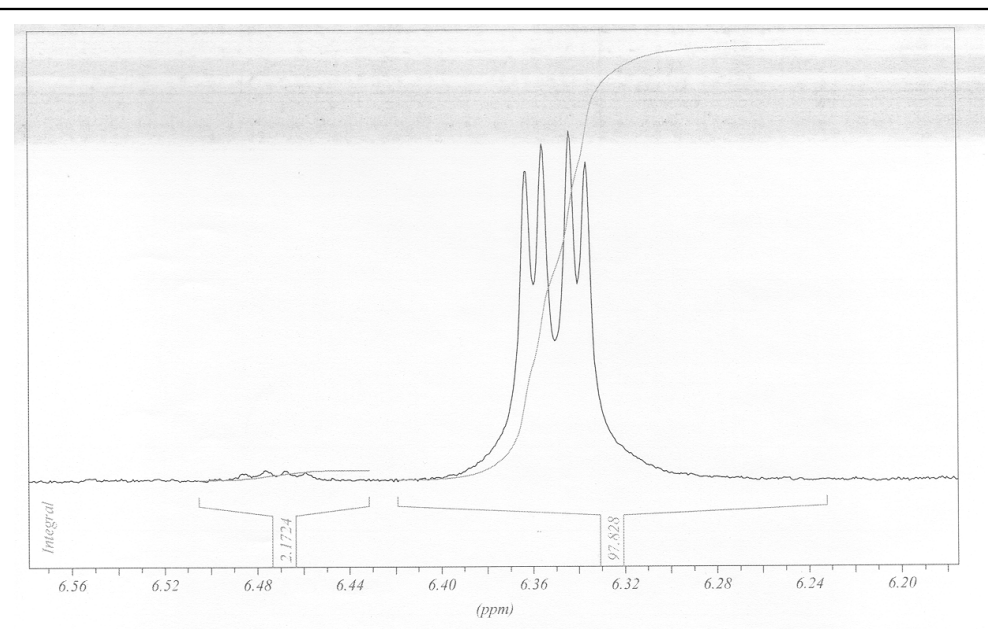


${ }^{1} \mathrm{H}$ NMR-spectra of the product 1(methoxypheny)ethane-1,2-diol from the $\mathrm{NaClO}_{2}$-dihydroxylation of $p$ methoxystyrene $(200 \mathrm{MHz}, d$ acetone).<smiles>COc1ccc(C(O)CO)cc1</smiles>

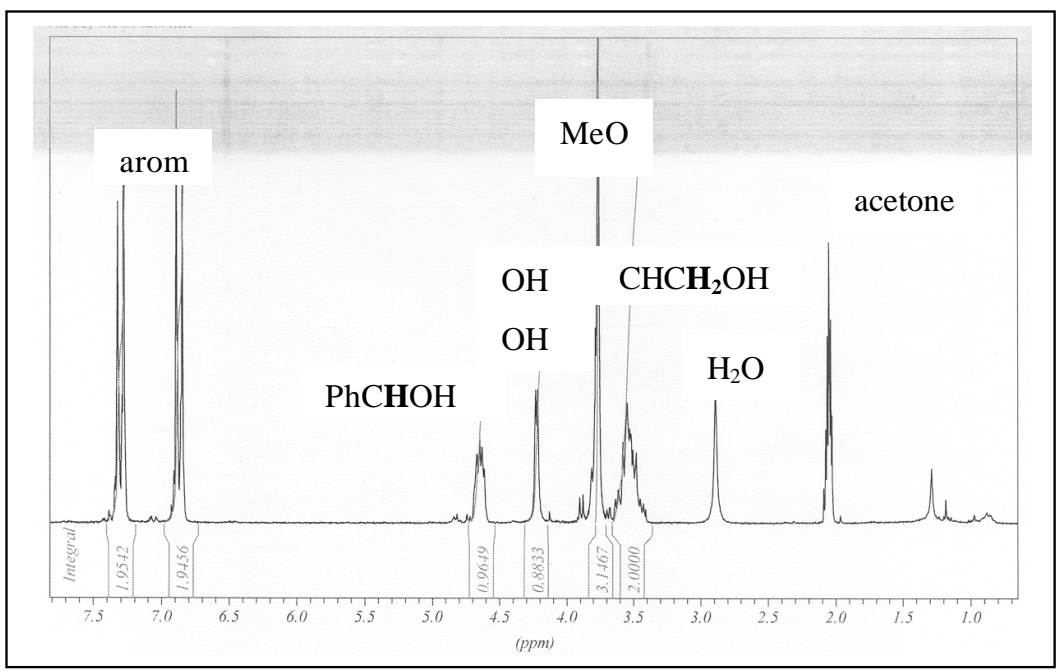

${ }^{1} \mathrm{H} \quad \mathrm{NMR}$ spectra of the bis(Mosher's)ester of the product from the $\mathrm{NaClO}_{2}$-dihydroxylation of $p$ methoxystyrene (400 MHz, $d$-acetone). ${ }^{1}$<smiles>COc1ccc(C(COC(=O)C(OC)(c2ccccc2)C(F)(F)F)OC(=O)C(F)(c2ccccc2)C(F)(F)F)cc1</smiles>

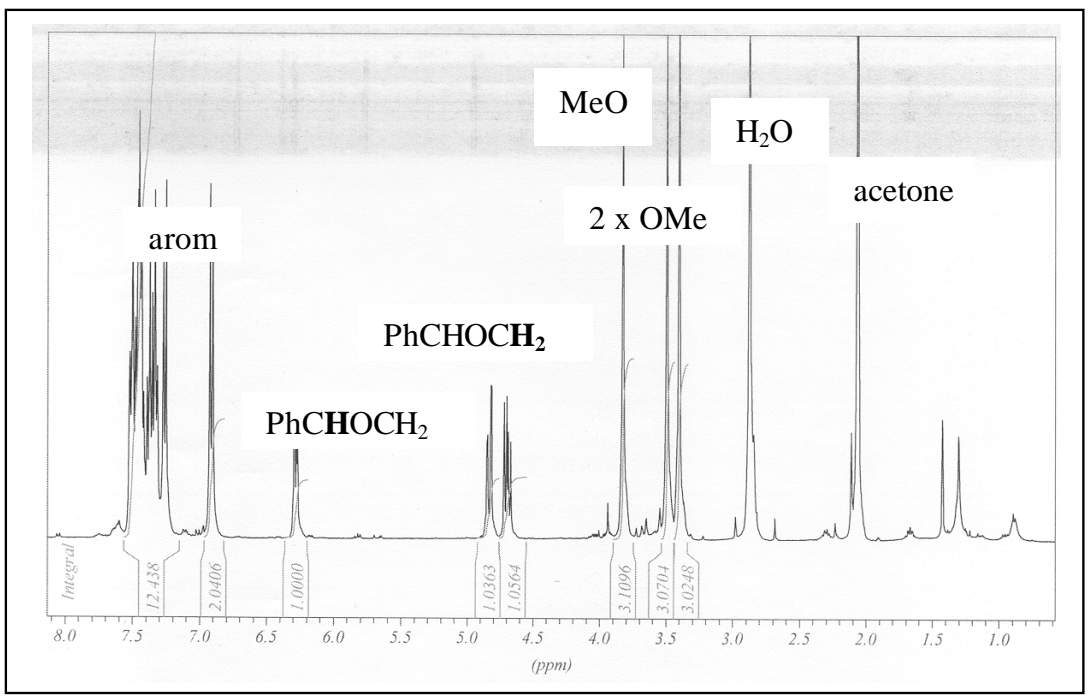

$\mathrm{PhCHOCH}_{2}$

$\mathrm{Ee} \%=99.38-0.62=98.76$

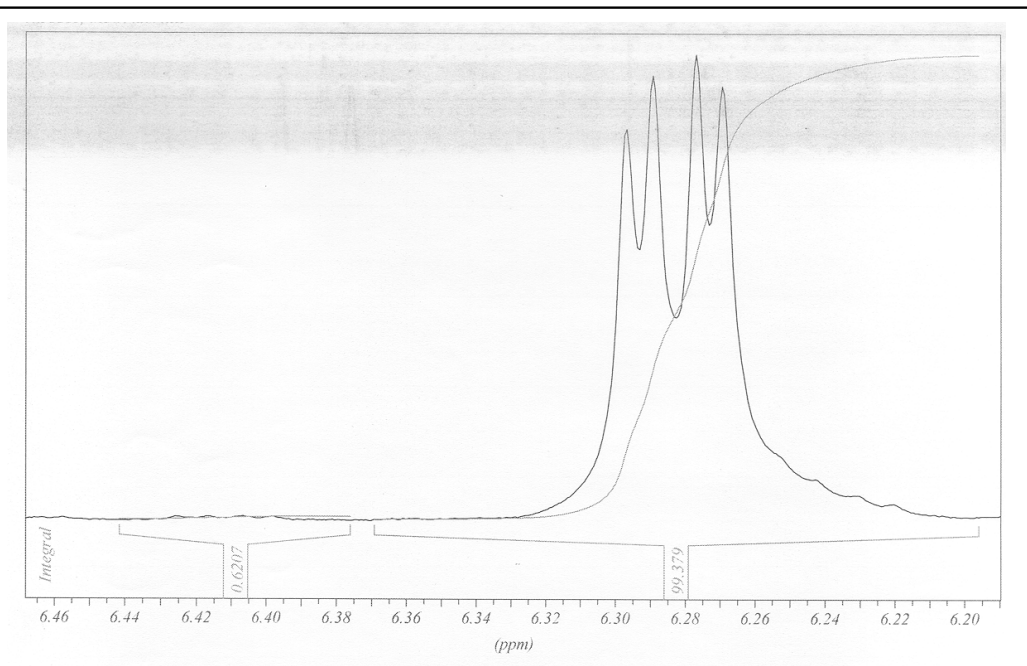


${ }^{1} \mathrm{H}$ NMR-spectra of the product 1(methoxypheny)ethane-1,2-diol from the $\mathrm{K}_{3}\left[\mathrm{Fe}(\mathrm{CN})_{6}\right]$-dihydroxylation of $p$-methoxystyrene $(200 \mathrm{MHz}, d$ acetone).<smiles>COc1ccc(C(O)CO)cc1</smiles>

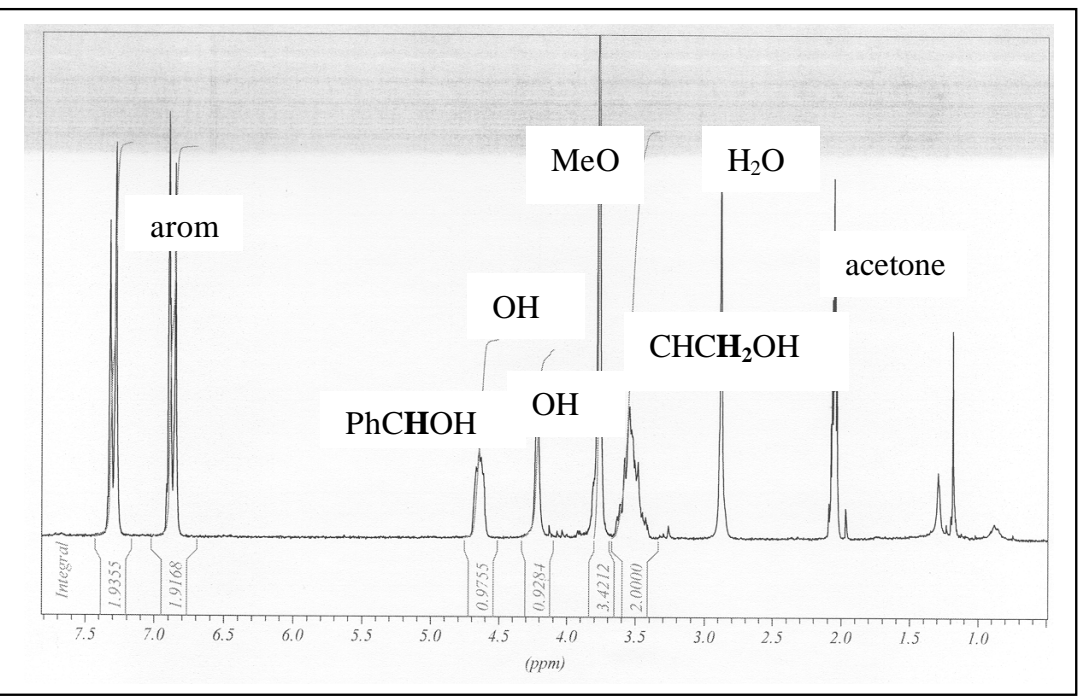

${ }^{1} \mathrm{H} \quad \mathrm{NMR}$ spectra of the bis(Mosher's)ester of the product from the $\mathrm{K}_{3}\left[\mathrm{Fe}(\mathrm{CN})_{6}\right.$-dihydroxylation of $p$-methoxystyrene (400 $\mathrm{MHz}, d$-acetone). ${ }^{1}$<smiles>COc1ccc(C(COC(=O)C(OC)(c2ccccc2)C(F)(F)F)OC(=O)C(F)(F)C(F)(F)F)cc1</smiles>

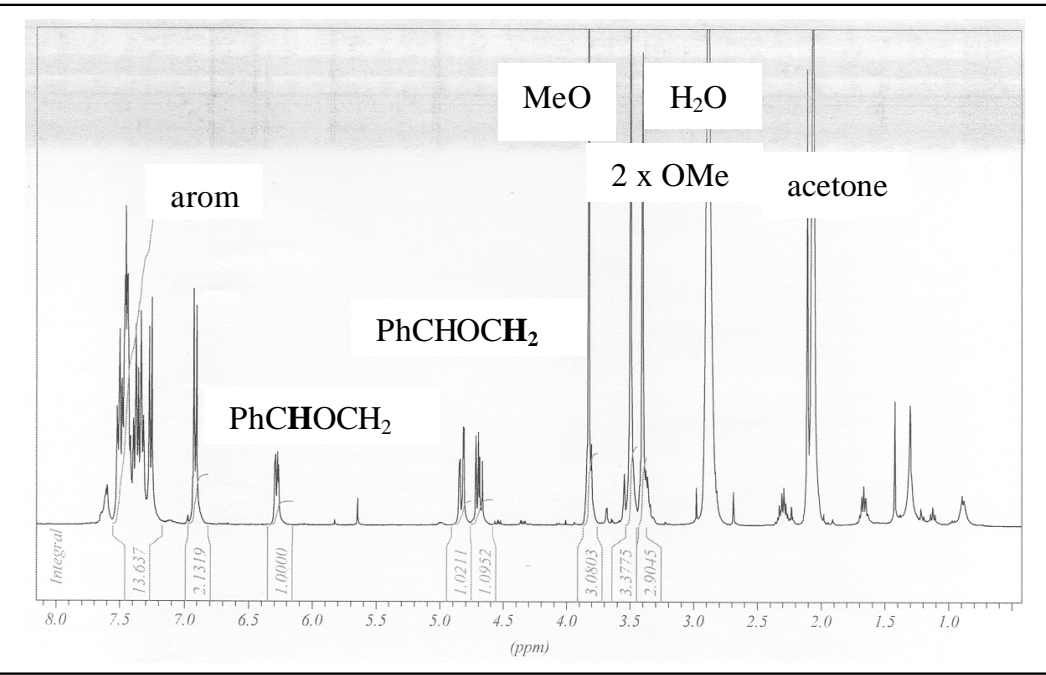

$\mathrm{PhCHOCH}_{2}$

$\mathrm{Ee} \%=99.47-0.53=98.94$

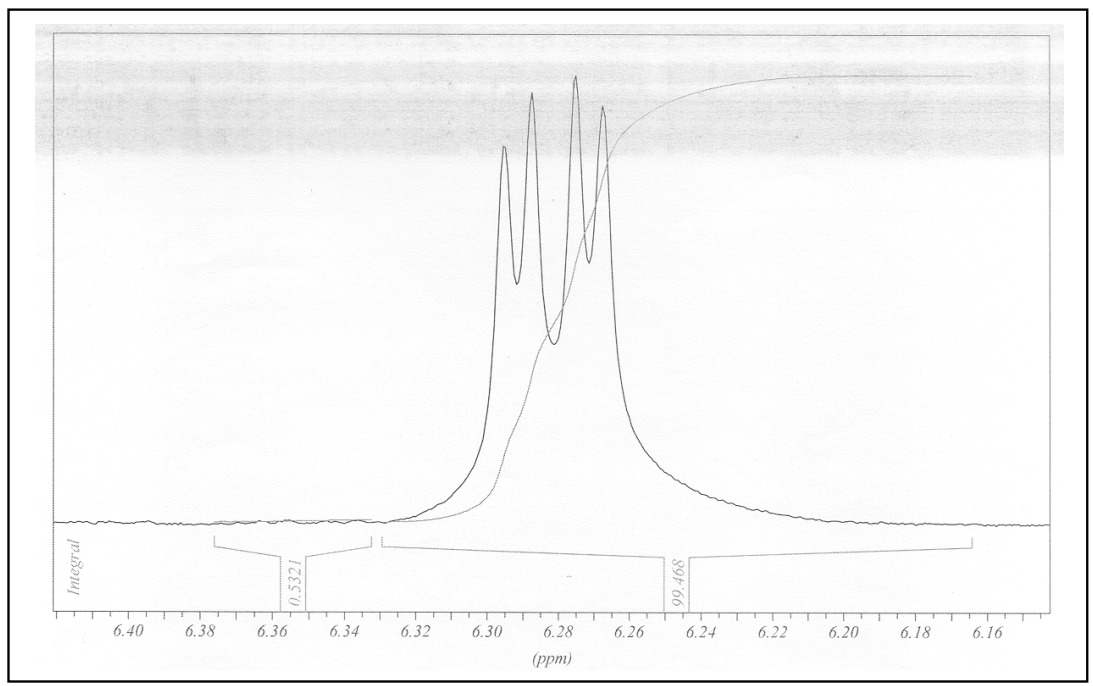


${ }^{1} \mathrm{H}$ NMR-spectra of the product 4-(1,2dihydroxyethyl)benxonitrile from the $\mathrm{K}_{3}\left[\mathrm{Fe}(\mathrm{CN})_{6}\right]$-dihydroxylation of $p$ cyanostyrene (200 MHz, $d$-acetone).<smiles>N#Cc1ccc(C(O)CO)cc1</smiles>

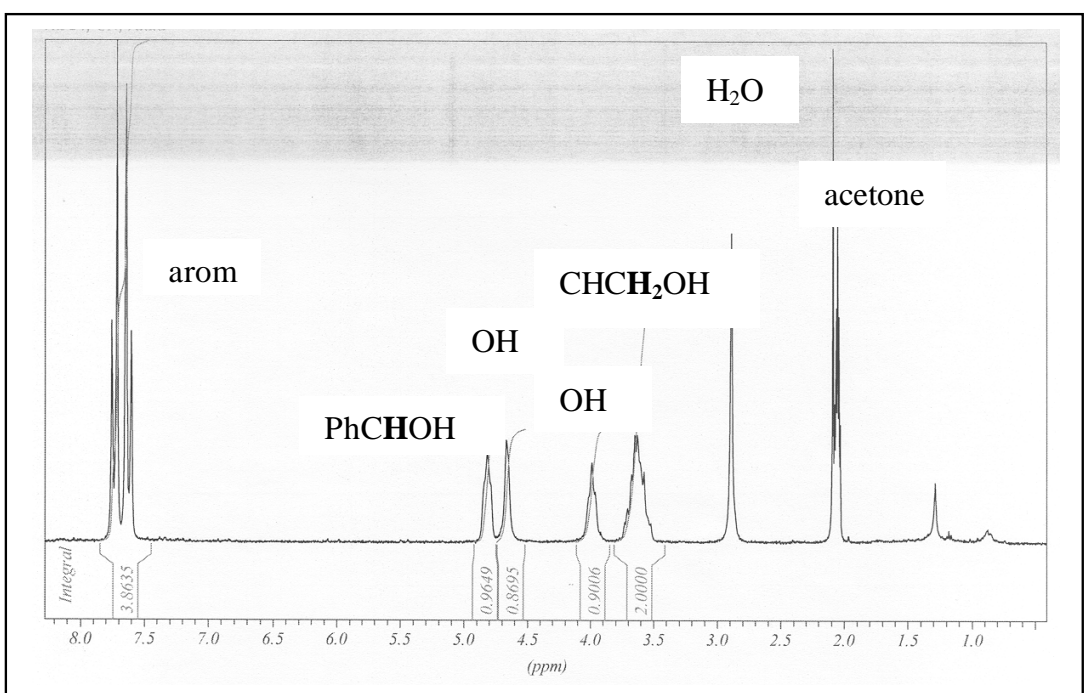

${ }^{1} \mathrm{H} \quad \mathrm{NMR}$ spectra of the bis(Mosher's)ester of the product from the $\mathrm{K}_{3}\left[\mathrm{Fe}(\mathrm{CN})_{6}\right.$-dihydroxylation of $p$ cyanoystyrene (400 MHz, $d$-acetone). ${ }^{1}$<smiles>COC(C(=O)OCC(OC(=O)C(OC)(c1ccccc1)C(F)(F)F)c1ccc(C#N)cc1)(c1ccccc1)C(F)(F)F</smiles>

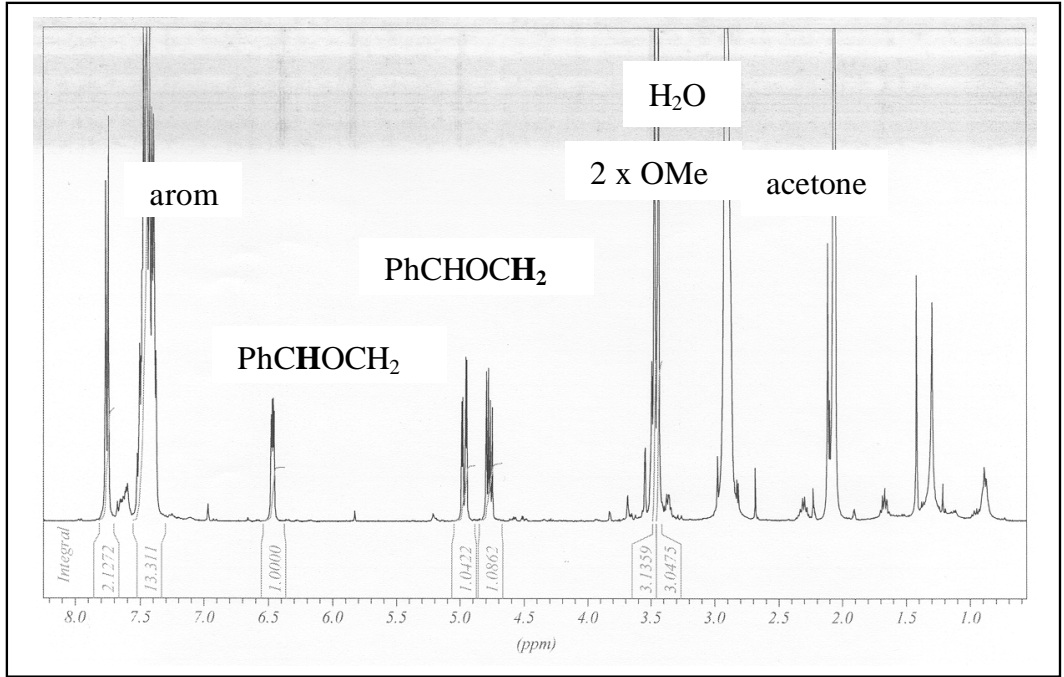

$\mathrm{PhCHOCH}_{2}$

$\mathrm{Ee} \%=99.53-0.47=99.06$

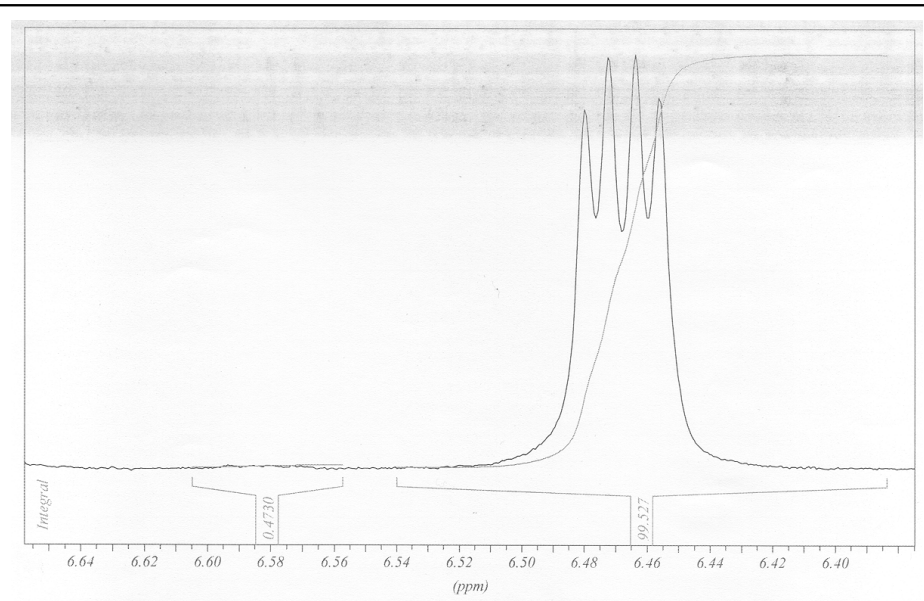


${ }^{1} \mathrm{H}$ NMR-spectra of the product 4(1,2-dihydroxyethyl)benxonitrile from the $\mathrm{NaClO}_{2}$-dihydroxylation of $p$-cyanostyrene $(200 \mathrm{MHz}, d$ acetone)<smiles>N#Cc1ccc(C(O)CO)cc1</smiles>

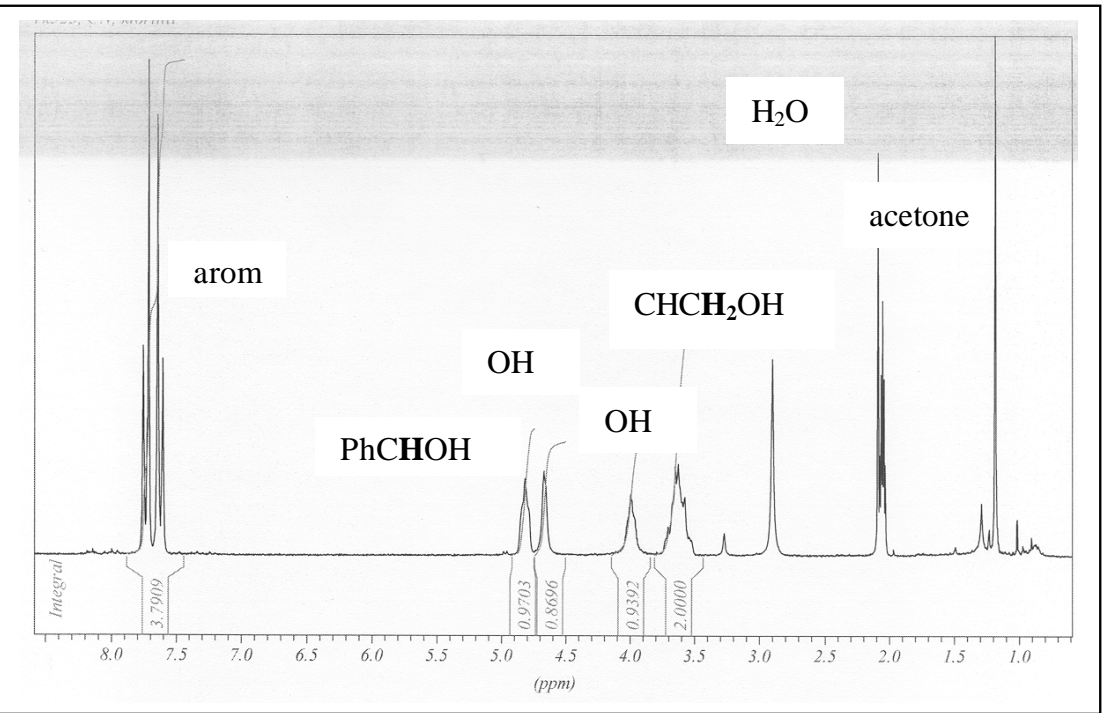

${ }^{1} \mathrm{H}$ NMR spectra of the bis(Mosher's)ester of the product from the $\mathrm{NaClO}_{2}$-dihydroxylation of $p$-cyanoystyrene $(400 \mathrm{MHz}, d$ acetone). ${ }^{1}$<smiles>COC(C(=O)OCC(OC(=O)C(F)(c1ccccc1)C(F)(F)F)c1ccc(C#N)cc1)(c1ccccc1)C(F)(F)F</smiles>

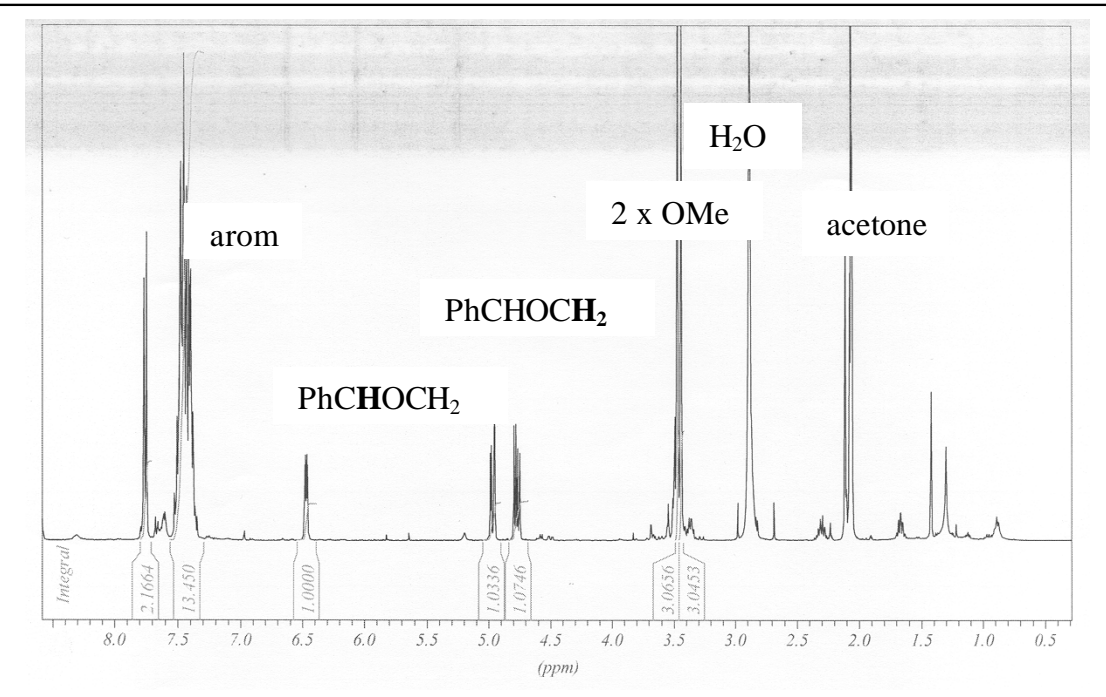

$\mathrm{PhCHOCH}_{2}$

Ee $\%=98.91-1.09=97.82$

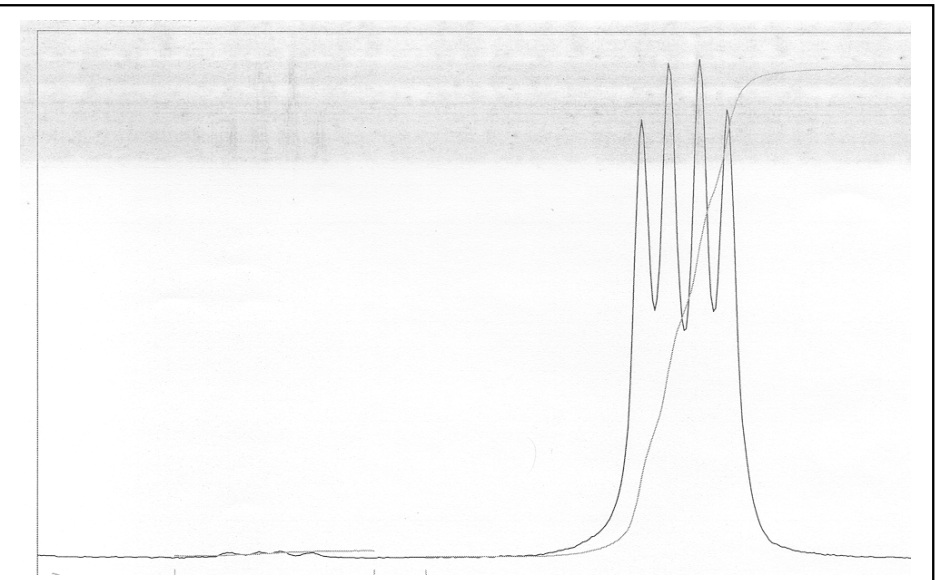

(1) Dale, J. A.; Mosher, H. S., J. Am. Chem. Soc. 1973, 95, 512-519 